this necessitates having two of them. They each consist of a thick wire 50 centimetres long, lying in the "focal line," and of a thin wire, 15 centimetres long, attached to one end at right angles, and which passes out to the back of the mirror through a hole in the zinc, where the sparking can be viewed, without obstructing the radiation in front. The total length of each "resonator" is about two wave-lengths, the wave-length being about 33 centimetres, so that it may be that there are two vibrating segments in each of these "resonators."

With this apparatus it is possible to deal with definite angles of incidence. No effect was obtained with glass plates using these mirrors, whether the "vibrator" was perpendicular to the plane of reflection or in it. But with a wall 3 feet thick reflection was obtained, when the "vibrator" was perpendicular to the plane of reflection ; but none, at least at the polarizing angle, ${ }^{1}$ when turned through $90^{\circ}$ so as to be in it.

This decides the point in question, the magnetic disturbance being found to be in the plane of polarization, the electric at right angles. Why the glass did not reflect was probably due to its thinness, the reflection from the front interfering with that from the back, this latter losing half a wave-length in reflection at a surface between a dense and a rare medium; and, as Mr. Joly pointed out, is in that case like the black spot in Newton's rings, or more exactly so, the black seen in very thin soap-bubbles. Hertz has pointed out several important things to be guarded against in making these

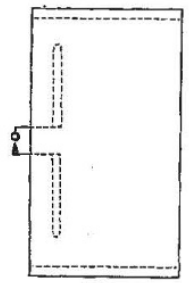

Fig. 4 .

experiments. Ultra-violet light, for example, falling on the "vibrator," prevents it working properly, the sparking in the resonator ceasing or becoming poor. Also, the knobs of the "vibrator" must be cleaned, of burnt metal, and polished every quarter of an hour at least, to prevent a like result.

Both these effects probably arise, as suggested by $\mathrm{Mr}$. Fitzgerald, from a sort of initial brush discharging (either ultra-violet light or points being capable of doing this), which prevents the discharging impulse being sufficiently sudden to start the oscillation in the "vibrator." For, to start a vibration, the time of impulse must be short compared with the time of oscillation. These precautions, therefore, become especially needful when working with small-sized "vibrators." Possibly, charging the "vibrator" very suddenly, after the manner of one of Dr. Lodge's anti-lightning-rod experiments, would save the irksome necessity of repeatedly cleaning the knobs of the "vibrator."

Several important problems seem to be quite within reach of solution by means of these Hertzian waves, such as dispersion. Thus, it could be tried whether placing between the reflector and the "resonator" conducting bodies of nearly the same period of vibration as the waves used would necessitate the position of the "resonator" being changed so as to retain complete interference. Or again, whether interspersing throughout the mass of a large Hertzian pitch-prism conductor with nearly the same period would alter the angle of refraction. In some such way as this, anomalous dispersion, with its particular case of ordinary dispersion, may yet be successfully imitated.

${ }^{1}$ Slight reflection was obtained at an incidence of $70^{\circ}$.
The determining the rate of propagation through a a large tile, or sheet of sandstone, could be easily made by means of the interference experiment, by placing it between the screen and the "resonator."

FRED. T. TROUTON.

\section{THE SCHOOL OF FORESTRY AT DEHRA DOON, INDIA.}

I AST year we gave an account of the newly-established School of Forestry at Cooper's Hill, the first of the kind in the United Kingdom, and explained what kind of instruction was there given, and how it was suited to the training of officers for the Indian Forest Department. We now propose to say something of its brother in India - an elder brother, indeed, by some eight years - the School at Dehra Doon, in the North-Western Provinces, now engaged in the education of those who may, not inaptly, be called the non-commissioned officers of the Department. The Dehra Doon is a long valley, which lies at the foot of that portion of the Himalaya which stretches between the great rivers Jumna and Ganges. It is shut off from the great Gangetic plain by a range of hills called the "Siwaliks," known well to all students of palæontological geology as the range in which were found the wonderful series of bones of extinct mammals described by Messrs. Falconer and Cautley. The valley itself lies about 2000 feet above the level of the sea, possesses a beautiful climate free from the blasts of the hot winds which, in April to June, sweep over the plains to the south of it; and is further known historically as having been the site of the first experiments made by the Indian Government in growing the tea-plant, experiments which proved its suitability to India, and made the Doon the fatherland of the great Indian tea industry-an industry which has gradually increased to such an extent that the exports of tea from India and Ceylon now very nearly rival in amount those from the Chinese Empire. Centrally situated in this beautiful valley, among plantations of tea, forests of sál-wood, and groves where the deodar of the Himalaya may be seen alongside of the mango, typical of the Indian plains, and feathery bamboos raise their heads from an undergrowth in which wild or semiwild roses thrive with luxuriance, lies the town of Dehra Doon, the head-quarters of a Deputy-Commissioner, of the offices of the great Trigonometrical Survey of India, of a regiment of Ghoorka troops, and of the body-guard of the Viceroy. It is rather a straggling town, like most similar Indian stations; but, centrally situated and surrounded by gardens, is found the Forest School, of which we wish to convey some idea to our readers. The School was first started, in 1878 , by the exertions of the then Inspector-General of Forests, now Sir Dietrich Brandis, K.C.I.E., and the first Director was Lieut.-Colonel F. Bailey, of the Royal Engineers.

At present the Director is Mr. W. R. Fisher, B.A. of Cambridge University, who is assisted by a Professor of Forestry, Mr. E. E. Fernandez, and a Professor of Geology and Chemistry, Dr. H. Warth. Mr. Fisher himself lectures on forest botany, while other officers, attached to the School for the management of the adjacent forests, teach mathematics, forest law, forest entomology, and surveying, the teaching of the last-named subject being especially fostered by the presence, in the same building, of the office of the Forest Survey, which is now engaged in the preparation of careful detailed maps of the great forest estate which Government possesses in India, and which bids fair to become, not only by its agricultural and climatic effects, but by its financial success, one of the most valuable of the revenue-yielding departments of the Empire.

Attached to the School is a well-equipped museum, containing a magnificent collection of accurately-named 
Indian woods ; an herbarium, a chemical laboratory, and a meteorological observatory; while the forests of three districts are attached to the School as a training-ground, in which the young students may learn, by personal and actual experience, the conduct of forest operations in the field. The students are usually selected in the different provinces by the Conservators of Forests, and are generally young officers who have seen already some preliminary service. Several have been deputed by the chief native States, such as Mysore and Baroda, and this shows the spread that an enlightened forest policy is making in the country. There are, besides, a number of independent students, who study in the hope of obtaining appointments if successful, either in the British territory or in the native States.

Two courses of study are carried on at the School, the higher in English, leading up to the ranger's certificate, which qualifies the students who succeed in obtaining it for the appointment as "Forest Ranger," on salaries rising from Rs. 600 to Rs. 3000 yearly ; the lower, in Hindustani, leading to the forester's certificate, which qualifies the holder for appointments of from Rs. 240 to Rs. 480 per annum. The ranger's course lasts twenty-one months, of which eight are spent in theoretical instruction, and the rest in practical work in the field. The subjects taught are forestry, botany, the elements of zoology, chemistry, physics, geology, mathematics, and surveying, with elementary engineering, such as road-making and the construction of forest export works, and forest law. The forester's course lasts sixteen months, four in theoretical study, and the rest in the field, and the subjects taught are elementary forestry and botany, mathematics, surveying and plan-drawing, and departmental procedure.

The students wear a neat uniform of kharki, drill with a turban or helmet, and they are regularly exercised in drill, most of the European and Eurasian students, however, preferring to join the Dehra Doon Corps of Mounted Infantry. When on tour in the forests on practical instruction, each has a small tent, with furniture of a camptable, chair, and bedstead, and some of them amuse themselves occasionally in sport, one student last year distinguishing himself by carrying off the first prize for shooting in the province.

The forests attached to the School Circle consist of those of the Dehra Doon, Saharanpore, and Jaunsar Forest Divisions. The two former contain chiefly forests of the sál tree (Shorea robusta), the chief gregarious tree of India, and the most valuable timber, for building purposes, after teak. They occupy respectively the northern and southern slopes of the Siwalik Range, and are carefully managed as training forests. The Dehra Doon forests are now being worked under a working plan prepared by Mr. Fernandez, the Professor of Forestry. These forests had, till some twenty years ago, been very badly treated, so that at present the older portion of the stock consists chiefly of trees which are crooked and unsound, the good and sound ones having previously been all cut out to provide sleepers for the East Indian, and Sind, Punjab, and Delhi Railways. The present working plan provides for a temporary rotation of twenty years, during whicb (I) all the old, unsound, and crooked sál trees which can be cut without letting in too much light are removed; and (2) all trees of the less valuable kinds that are not required for shade are cut away. These operations have now been carried on for a few years with the most beneficial results, for the ground is being rapidly covered with good and straight saplings and coppice shoots of sál. The forest operations, the selection of the trees to be cut, and their marking and enumeration, are all done by the students themselves, so that in this way they obtain a valuable amount of practical experience.

The forests of Jaunsar lie on the hills of the outer
Himalaya at an elevation of some 5000 to ro,000 feet, and consist chiefly of coniferous trees. The deodar cedar (Cedrus Deodara) is, of course, the most valuable of these ; then come the pines, the "kail" (Pinus excelsa), which so often accompanies the deodar, and the "chir" (Pinus longifolia), which forms gregarious forest at the lower elevations. The silver and spruce firs (Abies Webbiana and Smithiana) also occur, as well as oaks (Quercus incana, dilatata, and semicarpifolia) and other temperate trees. These forests are also carefully treated under working plans, and in them the students of the School learn the management of coniferous forests, the extraction of timber by roads and slides, the planting of blanks in the forest, and the measures necessary for protection against fire and frost.

At the end of their course, and on obtaining their certificates, the students return to the provinces from which they were sent, qualified to carry out ordinary forest works in their own country; and some of them have already obtained promotion into the higher staff of the Department as the reward of their good work, industry, and energy.

The Forest School at Dehra Doon may thus be said to be doing an excellent work, a work which cannot fail to have the best possible effect in the country, and to show the truth of Sir Edwin Arnold's saying that "the Forest Conservancy carried out by the British 'Râj' is one of the greatest benefits to the peninsula."

Soon, perhaps, the extension of forest work will necessitate the establishment of other or branch establishments in Madras, Burmab, and elsewhere ; but it is to Dehra Doon that all will look up as the pioneer of scientific forest teaching for the natives of our great dependency.

\section{THE GIANT EARTHWORM OF GIPPSLAND.}

THE recently-issued first part of the Transactions of the Royal Society of Victoria contains an elaborate essay (of which we have something to say elsewhere today) by Mr. Baldwin Spencer, the newly-appointed Professor of Zoology in the University of Melbourne, on the anatomy of the Giant Earthworm of Gippsland, the largest earthworm yet known. This worm, of which some examples attain to the extraordinary length of six feet, was first described by Prof. McCoy in 1879, and named Megascolides australis. It belongs to a peculiar Australian group, of which five species are now known. $\mathrm{Mr}$. Spencer gives us the following general account of its habits :--

Of all the species of Megascolides yet known, this one seems to be the largest, and is apparently confined to Gippsland; it is, when found at all, somewhat abundant, and lives principally on the sloping sides of creeks. At times it is found beneath fallen logs, and may be turned out of the ground by the plough.

When first seeking it, we were somewhat puzzled by some of those who were evidently well acquainted with the worm assuring us that the entrance to its burrow was indicated by a distinct "casting"; whilst others, evidently equally well acquainted with the animal, were quite as positive in asserting that it never produced any " casting." Whilst searching, we found what I believe to be the explanation of the contradictory statements, and soon discovered that the surest test of the presence of the worm underground was a very distinct gurgling sound, made by the animal retreating in its burrow when the ground was stamped upon by the foot. When once heard, this gurgling sound is unmistakable, and we at once learnt to regard it as a sure sign of the worm's presence.

The worm very frequently lives in ground riddled by the holes of the land-crab, as it is popularly called; this animal has a small circular burrow leading down to a 